\title{
ECONOMIC AND MATHEMATICAL MODELING OF INVESTMENT ATTRACTIVENESS OF CONSTRUCTION ENTERPRISES IN THE SYSTEM OF STAKEHOLDER RELATIONS
}

\author{
Volodymyr Velychko', Evgeniy Grytskov², Dmytriy Prunenko³
}

\begin{abstract}
The relevance of the process of implementation of economic and mathematical model of investment attractiveness of the construction enterprise in the stakeholder relation system is proved. The results of the analysis of the theoretical provisions for determining investment attractiveness and stakeholders of construction enterprises are presented. An economic and mathematical model for the formation of stakeholder groups in the system of relations with construction enterprises is proposed. A system of information and analytical support for an integrated assessment of the level of stakeholder relations and investment attractiveness of construction enterprises has been formed, which creates the basis for economic and mathematical modeling. The directions, methods, and models for assessing investment attractiveness and the level of stakeholder relations of construction enterprises are proposed. Thepractical aspects of theirimplementation are determined. The results of economic and mathematical modeling of the investment attractiveness of construction enterprises in the system of stakeholder relations are presented. The subject of the research is the directions of formation and realization of economic and mathematical modeling of investment attractiveness of enterprises in the system of stakeholder relations. The formation of the research methodology is carried out on the basis of the theoretical and methodological platform for determining the investment attractiveness of enterprises and stakeholders that interact in the relevant field. In addition, a set of methods is used to conduct the study: analytical (to determine indicators of investment attractiveness); expert assessments (to determine the index of stakeholder relations); method of analysis of hierarchies (to assess the importance of the impact of stakeholders (customers of construction products; workers of construction enterprises; top management; managers of various levels of construction enterprises; owners of construction enterprises; government bodies influencing the formation and level of interaction of stakeholders with construction enterprises; public organizations influencing activities in construction and architecture; corporate governance bodies of construction enterprises; the bodies of internal and external control interacting in the construction industry; the competitors of construction enterprises; the suppliers of inventories interacting with construction enterprises; stakeholders interacting in the formation and use of spatial, urban, environmental information and creating investment attractiveness of construction enterprises; the design organizations; other stakeholders interacting with construction enterprises) at the level of stakeholders from noses of enterprises); economic and mathematical modeling (to establish causal links between the level of stakeholder relations and the index of investment attractiveness of enterprises); generalization and systematization (to obtain and interpret research results). The aim of the study is to establish causal relationships between the factors that shape the level of stakeholder relations and investment attractiveness of construction companies based on economic and mathematical tools. The result of the study is the formation of a quantitative basis for making sound management decisions in the system of stakeholder relations of construction companies to increase their investment attractiveness.
\end{abstract}

Key words: investment attractiveness, level of stakeholder relations, construction enterprises, economic and mathematical modeling, adequacy criteria, model.

JEL Classification: E62, H2O, H50

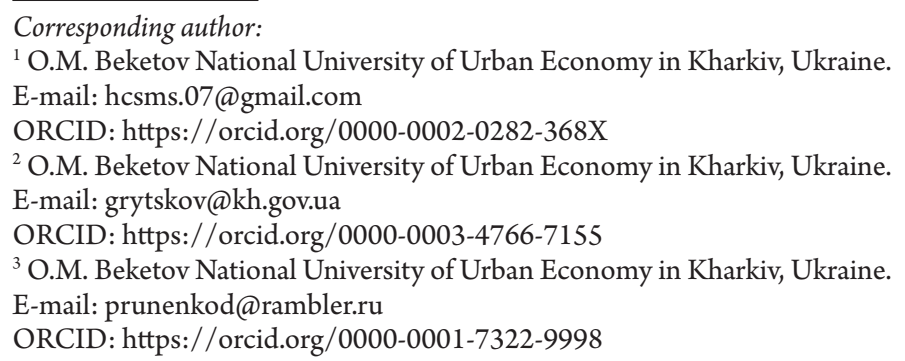




\section{Introduction}

In current conditions, the functioning of the construction sector companies affects the development of the state economy and ensures the activity of other areas. In particular, enterprises in the construction sector determine the directions of more than 30 areas. In the international practice, the importance of areas of interaction between stakeholders that affect the functioning of companies that ensure their investment attractiveness and development is growing. In particular, the areas and features of interaction with stakeholders, their importance in the system of functioning of companies are formed and presented in the Danish Civil Code (1907), the Swiss Code of Obligations (1911), Normative legal documents on collective bargaining regulation of labor relations in Germany (1918), Finland (1924), "The Freedom of Association and Protection of the Right to Organise Convention" (1948, No. 87), The Right to Organise and Collective Bargaining Convention (1949, No. 98), Collective Agreements Recommendation (1951, No. 91), Cooperation at the Level of the Undertaking Recommendation, (1952, No. 94), Collective Bargaining Convention, (1981, No. 154), etc. Therefore, the determination of the influence of stakeholders on the activities of construction enterprises and their investment attractiveness is of particular importance. This study aims to determine the processes of economic and mathematical modeling of investment attractiveness of construction enterprises through the formation and implementation of stakeholder relations by determining the relationship between the integrated systemic of investment attractiveness and the generalizing factor of the level of stakeholder relations based on the application of the method of correlation and regression analysis and model adequacy criteria. This approach allows to develop strategic directions, to determine the promising contours of the construction enterprises development, to carry out their forecasting, considering the types and characteristics of interaction with stakeholders. In recent years, more and more attention has been focused on ensuring the investment attractiveness of companies and accounting for stakeholder relationships, as in many other areas of the economy. In (Parmar et al., 2010; Donaldson and Preston, 1997; Preston, 2004; D'Anselmi, 2011), the directions and peculiarities of stakeholder interaction in the process of enterprise functioning are defined. The importance of determining the investment attractiveness of enterprises is indicated in (Dearden, 1987; Post et al., 2002; Krylova et al., 2003; Sabluk et al., 2005).

Section 2 of the study summarizes the scientific developments to determine theinvestmentattractiveness of construction enterprises and stakeholders that affect them. Section 3 provides information and analytical support for the implementation of economic and mathematical modeling of investment attractiveness in the system of stakeholder relations, presents the results of the integrated assessment of investment attractiveness and level of stakeholder relations of enterprises in the construction sector. In Section 4, the methods and directions of economic and mathematical modeling are substantiated, the criteria of adequacy are defined. Section 5 is devoted to the results of economic and mathematical modeling of the systemic factor influence of the stakeholder relations level on the investment attractiveness integrated index for construction enterprises. Section 6 presents the results of the study.

\section{Literature review}

Existing scientific approaches are characterized by various aspects of determining the investment attractiveness of enterprises. In particular, Valinurova and Kazakova (2005) and Krylova et al. (2003) assess investment attractiveness based on indicators of efficiency and effectiveness and form the resulting approach. In developing the presented method, Sabluk et al. (2005) consider the investment attractiveness in terms of its integrated criteria for the validity of investment conditions, which ensure the personal interest of investors to invest capital in multiplying it or obtaining social effect. Burkovets (2012) defines investment attractiveness from the socio-economic feasibility of funding based on the coordination of the interests and capabilities of the investor and the recipient of investments, ensuring the achievement of the goals of each of them with the accepted level of return and investment risk. A similar approach is presented in (Duka, 2008).

In contrast to the previous approach, Korotkova (2013) considers investment attractiveness from the point of view of factors forming and influencing it: external (industry affiliation; geographical position; availability and accessibility of natural resources ecological situation; culture and education of the population; environmental sustainability; sociopolitical stability; legal and regulatory framework; information field; incentives for investors; developed infrastructure; economic freedom of the enterprise; position in the world market; controlling state bodies in the area of investment; inflation rate; export opportunity; population income level; industry competition); internal (production program; marketing activities; management accounting and controlling; corporative management; staffing potential; legal activity; production technologies; development strategy; competitiveness; the uniqueness of the object; duration of the investment program; company rating in the industry; payment discipline; condition of property and financial resources; expenses; capital structure (Duka, 2008). A similar approach is developed in (Budnikova, 2011; Kuntsevich, 2005; Ovdiy et al., 
2009). Representatives of the factor approach (Shportko et al., 2014) distinguish the following groups of factors: - financial condition (debt to equity ratio, current liquidity, asset turnover, return on equity on net income, return on sales on net income);

- market environment (the investment climate in the region, the investment attractiveness of the industry, the geographic market for the enterprise, the stages of the product life cycle, the degree of competition in the market, the environmental burden on the environment, the development of transport infrastructure);

- corporate governance (government influence on business management, the proportion of shares in free circulation on the secondary market, the amount of remuneration to the board members, financial transparency and disclosure of information, the rights of shareholders, the level of dividend payment) (Ovdiy et al., 2009).

In the framework of the factor approach, factors that form the investment attractiveness of the enterprises are determined (Bilyak, 2006; Yuriy and Hubanova, 2005; Mayorova, 2004; Orlykovsky, 2007; Shiyan and Strochenko, 2003; Vovchak, 2006; Maidanevich, 2004). A comprehensive approach to determining investment attractiveness has been developed in (Rud, 2006; Dudka and Lysenko, 1999; Savchuk et al., 1999; Leshchenko, 2001; Florko, 2003), which is characterized by financial indicators, market features and characteristics, internal and external factors.

Some authors define the following features and characteristics of the investment attractiveness of the enterprise: its general characteristics, directions and features of the formation and use of the production and technical base, production and economic potential, types, and nomenclature, characteristics of the management system, the company's place in the industry, financial condition, interaction with owners (Malova and Silverstova, 2003).

The representative of the sophisticated approach is Kostyuk (2005), who considers the investment attractiveness in terms of its system characteristics, which are determined by a set of rules and conditions for investing resources in a particular object at a specific time. Laiko (2005) characterizes investment attractiveness as a complex of production and financial quantitative and qualitative conditions and criteria, which characterize their potential opportunities and economic advantages in comparison with other objects of investment. When implementing an integrated approach, Stalinskaya (2003) defines the investment attractiveness as an integrated indicator that combines complex formalized and non-formalized criteria characterizing the advisability of investing in the analyzed potential object of investment. Chervanev (2003) characterizes investment attractiveness as a set of indicators of the financial and economic condition of an enterprise, based on which a potential investor can make a managerial decision on the feasibility of investing free funds in the development of this enterprise without significant risk of loss or non-receipt of the expected return on invested capital.

Thus, while sharing the provisions of the integrated approach, the study proposed the concept of investment attractiveness of enterprises as a systemic category, which is determined by a combination of factors, characteristics, and features, which define potential opportunities, investment, and economic advantages, form a quantitative basis for making informed management decisions and ensuring the development of enterprises. Based on the scientific provisions (Vlasova and Bezginova, 2006; Kolchkova, 2011; Pilyushenko and Shkrobak, 2000; State Statistics Service of Ukraine, 2011; Zhuvagina, 2013), it is proposed to evaluate the level of investment attractiveness of the enterprises based on an integrated approach.

As a result of the systematization of existing scientific approaches (Yukhimchuk and Suprun, 2003; Zyatkovsky, 2003; Ackoff, 1972; Ackoff and Emery, 2005; Cleland, 2004), the definition of stakeholders of construction enterprises was proposed. Stakeholders are characterized as individuals and (or) legal entities or groups of individuals who interact in the construction sector based on strategic circuits and social trends and are defined by functional, resultant, structural, process, strategic and complex features. The relationships of stakeholders have a certain level of risk and threats, which allows to form contractual relations in capital construction, carry out architectural control, relevant calculations, which are provided by project documentation, material, and labor resources.

The formed groups of stakeholders of construction enterprises as follows:

- customers of construction products $\left(S_{1}\right)$;

- workers of construction enterprises $\left(S_{2}\right)$;

- top management $\left(S_{3}\right)$;

- managers of various levels of construction enterprises $\left(S_{4}\right)$;

- owners of construction enterprises $\left(S_{5}\right)$;

- government bodies influencing the formation and level of interaction of stakeholders with construction enterprises $\left(S_{6}\right)$;

- public organizations influencing activities in construction and architecture $\left(S_{7}\right)$;

- corporate governance bodies of construction enterprises $\left(S_{8}\right)$;

- the bodies of internal and external control interacting in the construction industry $\left(S_{9}\right)$;

- the competitors of construction enterprises $\left(S_{10}\right)$;

- the suppliers of inventories interacting with construction enterprises $\left(S_{11}\right)$;

- stakeholders interacting in the formation and use of spatial, urban, environmental information and creating investment attractiveness of construction enterprises; - the design organizations $\left(S_{13}\right)$; 
- other stakeholders interacting with construction enterprises $\left(S_{14}\right)$.

The economic and mathematical model on the formation of stakeholders in the system of relations with construction enterprises is proposed:

$$
S=F\left(S_{j}\right), j=\overline{1,14} \text {, }
$$

where $\mathrm{F}$ is the factor of formation of stakeholder groups interacting with construction enterprises; $j$ is the number of types of stakeholders.

\section{Data and unit root tests}

To conduct the research, a system of information and analytical support for the integrated assessment of the level of stakeholder relations and investment attractiveness of construction enterprises based on accounting and financial reporting, data on contractual obligations, results of strategic management, use of production facilities, technologies and workers, peculiarities of formation and application of material and technical base, directions of relationships between different groups of stakeholders is formed. This provides the opportunity to generate complete and high-quality technical and economic information used in the construction industry and provides the basis for economic and mathematical modeling. Within the framework of information and analytical support, a system of factors is being formed that affects the level of stakeholder relations and the formation of investment attractiveness of construction enterprises, ensuring the development of a multi-level system of indicators. For the creation of information and analytical support and determination of factors, groups of stakeholders are selected based on the implementation of the following steps:

1. Formation of the total number of experts. The study identified 50 people $\left(n_{t}=50\right)$.

2. Definition of criteria $\left(k_{i}\right)$ for the selection of experts. These include:

2.1. The level of theoretical training of experts on the interaction of stakeholders of construction enterprises $\left(k_{1}\right)$.

2.2. Educational qualification level of experts $\left(k_{2}\right)$.

2.3. Experience in working with various stakeholder groups $\left(k_{3}\right)$.

2.4. Experience in the construction industry $\left(k_{4}\right)$.

2.5. Experience in expert groups $\left(k_{5}\right)$.

2.6. The experience of experts in advancing development programs for construction enterprises $\left(k_{6}\right)$.

2.7. Specialized education of experts $\left(k_{7}\right)$.

3. Formation of scale for the assessment criteria for the selection of experts and their characteristics. The scale value ranges from 0 to 10 .

4. Construction of a questionnaire for assessing the quality of experts on a specific scale, assessing the average value according to established criteria.
5. The adoption of the decision on the selection of experts from the average value. The expert remains if the average value by the criteria is equal to or more than 5 (meets or exceeds a moderate level).

6. Determination of the minimum number of experts ( $\mathrm{mmin}$ ) necessary for the study by the model:

$$
n_{t \text { min }}=0.5\left(\frac{3}{D k_{t}+5}\right) \text {. }
$$

The minimum number of experts required for the study is set at Level 3.

As a result of the study, 38 experts were identified through the application of the proper steps, the opinions of which will be taken into account to determine the stakeholder indicators and the level of investment attractiveness of construction enterprises.

\section{Empirical specification and method}

Taking into account the results of systematization of theoretical and methodological provisions, information and analytical, normative and legal provision for determining investment attractiveness, the directions for estimation of its level are proposed:

1. Formation of information and analytical support for determining the investment attractiveness of construction enterprises.

2. Determination of local factors that form the investment attractiveness of construction enterprises.

3. Formation of systemic factors for determining the investment attractiveness of construction enterprises.

4. Development of a multi-level system of indicators of investment attractiveness assessment.

5. Assessment of local factors in the formation of investment attractiveness of construction enterprises.

6. Assessment of systemic factors for determining investment attractiveness.

7. Building an integrated model for assessing the investment attractiveness of construction enterprises.

8. Determination of weight coefficients characterizing the influence of systemic factors on the integrated indicator of investment attractiveness.

9. Assessment of the integrated indicator of investment attractiveness of construction enterprises.

10. Interpretation of the results.

According to the proposed stages, an integrated economic and mathematical model has been built (3):

$$
\begin{aligned}
& I A=k_{I A_{1}} x I A_{1}+k_{I A_{2}} x I A_{2}+k_{I A_{3}} x I A_{3}+ \\
& +k_{I A_{4}} x I A_{4}+k_{I A_{5}} x I A_{5}+k_{I A_{6}} x I A_{6}+k_{I A_{7}} x I A_{7},
\end{aligned}
$$

where $I A$ is an integrated indicator of the investment attractiveness level of construction enterprises, rel. units; $I A_{1}, I A_{2}, I A_{3}, I A_{4}, I A_{5}, I A_{6}, I A_{7}$ are systemic indicators of the level of investment attractiveness of construction enterprises, rel. units; $k_{I A 1}, k_{I A 2}, k_{I A 3}, k_{I A 4}, k_{I A 5}, k_{I A 6}$, $k_{\text {IA7 }}$ are weighting factors that determine the influence of external market factors, internal factors, factors of wealth, 
financial stability, liquidity, business activity, the level of investment activity of construction enterprises on the formation of their investment attractiveness, rel. units.

The characteristics of the integrated indicator values of the investment attractiveness of construction enterprises are presented in Table 1.

Table 1

The characteristics of the integrated indicator values of investment attractiveness, rel. units

\begin{tabular}{|c|c|}
\hline $\begin{array}{c}\text { The value of the } \\
\text { integrated indicator }\end{array}$ & Characteristic \\
\hline 0 & $\begin{array}{c}\text { no investment attractiveness of construction } \\
\text { enterprises }\end{array}$ \\
\hline $0.01-1$ & insignificant \\
\hline $1.01-2$ & low \\
\hline $2.01-3$ & relatively low \\
\hline $3.01-7$ & moderate \\
\hline $7.01-8$ & relatively high \\
\hline $8.01-9$ & high \\
\hline $9.01-9.99$ & significant \\
\hline 10 and more & absolute \\
\hline
\end{tabular}

For an integrated assessment of the level of stakeholder relations of construction enterprises, a methodological approach scheme has been developed (Figure 1), which includes:

- formation of information and analytical support for providing an integrated assessment of the level of stakeholder relations;

- building an analytical and diagnostic system of indicators for the integrated assessment of the level of stakeholder relations;

- determination of factors of the third level in the integrated assessment system;

- development of models for determining systemic factors of second level;

- assessment of systemic factors of the second level of a multi-level system;

- building an integrated assessment model;

- assessment of weighting coefficients of mutual influence and the impact of systemic factors on an integrated indicator of stakeholder relations level;

- determination of the integrated indicator of stakeholder relations level;

- development of conclusions based on the assessment of stakeholder relations level in the context of the formation of a stakeholder-oriented strategy for managing construction enterprises using economic and mathematical modeling.

It should be noted that the analytical and diagnostic system of indicators for integrated assessment of stakeholder relations includes three levels:

Level 3: Includes local factors that are determined by analytical and expert methods;

Level 2: Formed from systemic factors that are determined by the models presented in the previous section. In general, systemic factors of second level are determined by:

$$
\begin{aligned}
& S_{1}=\left\langle S_{11}, S_{12}, \Omega\right\rangle,(4) \\
& S_{2}=\left\langle S_{21}, S_{22}, \ldots, S_{214}, \Omega\right\rangle,(5) \\
& S_{3}=\left\langle S_{31}, S_{32}, \ldots, S_{38}, \Omega\right\rangle,(6) \\
& S_{4}=\left\langle S_{41}, S_{42}, \ldots, S_{4103}, \Omega\right\rangle,(7) \\
& S_{5}=\left\langle S_{51}, S_{52}, \ldots, S_{571}, \Omega\right\rangle,(8) \\
& S_{6}=\left\langle S_{61}, S_{62}, \ldots, S_{632}, \Omega\right\rangle,(9)
\end{aligned}
$$

where $S_{1}$ is the systemic factor of quality and level of contractual obligations fulfillment, rel. units; $S_{2}$ is the systemic factor of the interaction level of the investigated construction enterprises with different groups of stakeholders, rel. units; $S_{3}$ is the systemic factor of formation and realization of corporate management of construction enterprises for ensuring interaction with stakeholders, rel. units; $S_{4}$ is a systemic factor, which provides stakeholder engagement in the context of the formation and implementation of strategic directions for the construction enterprises operation, rel. units; $S_{5}$ is the systemic factor that determines the socio-economic and innovative level of construction enterprises, which are provided through the interaction of stakeholders, rel. units; $S_{6}$ is the systemic factor of the strategic condition of construction enterprises, rel. units.; $\Omega$ is a set of relationships and links between factors, which influence the level of formation and implementation of stakeholder relationships.

Level 1: determines the integral indicator of the level of stakeholder relations $\left(I_{s}\right)$, which is formed based on systemic factors.

In general, models for determining the systemic factors influencing the level of formation and implementation of stakeholder relations and the model for determining the integrated factor of the stakeholder relations level are presented in Figure 1. The scale of integrated factor values for the stakeholder relations level is presented in Table 2.

Table 2

The scale of integrated factor values for the stakeholder relations level, rel. units

\begin{tabular}{|c|c|}
\hline $\begin{array}{c}\text { The value of the } \\
\text { integrated indicator }\end{array}$ & Level \\
\hline 0 & $\begin{array}{c}\text { there are no stakeholder relations } \\
\text { at construction companies }\end{array}$ \\
\hline $0.01-1$ & insignificant \\
\hline $1.01-2$ & low \\
\hline $2.01-3$ & relatively low \\
\hline $3.01-7$ & moderate \\
\hline $7.01-8$ & relatively high \\
\hline $8.01-9$ & high \\
\hline $9.01-9.99$ & significant \\
\hline 10 and more & absolute \\
\hline
\end{tabular}


Vol. 6, No. 4, 2020

Baltic Journal of Economic Studies

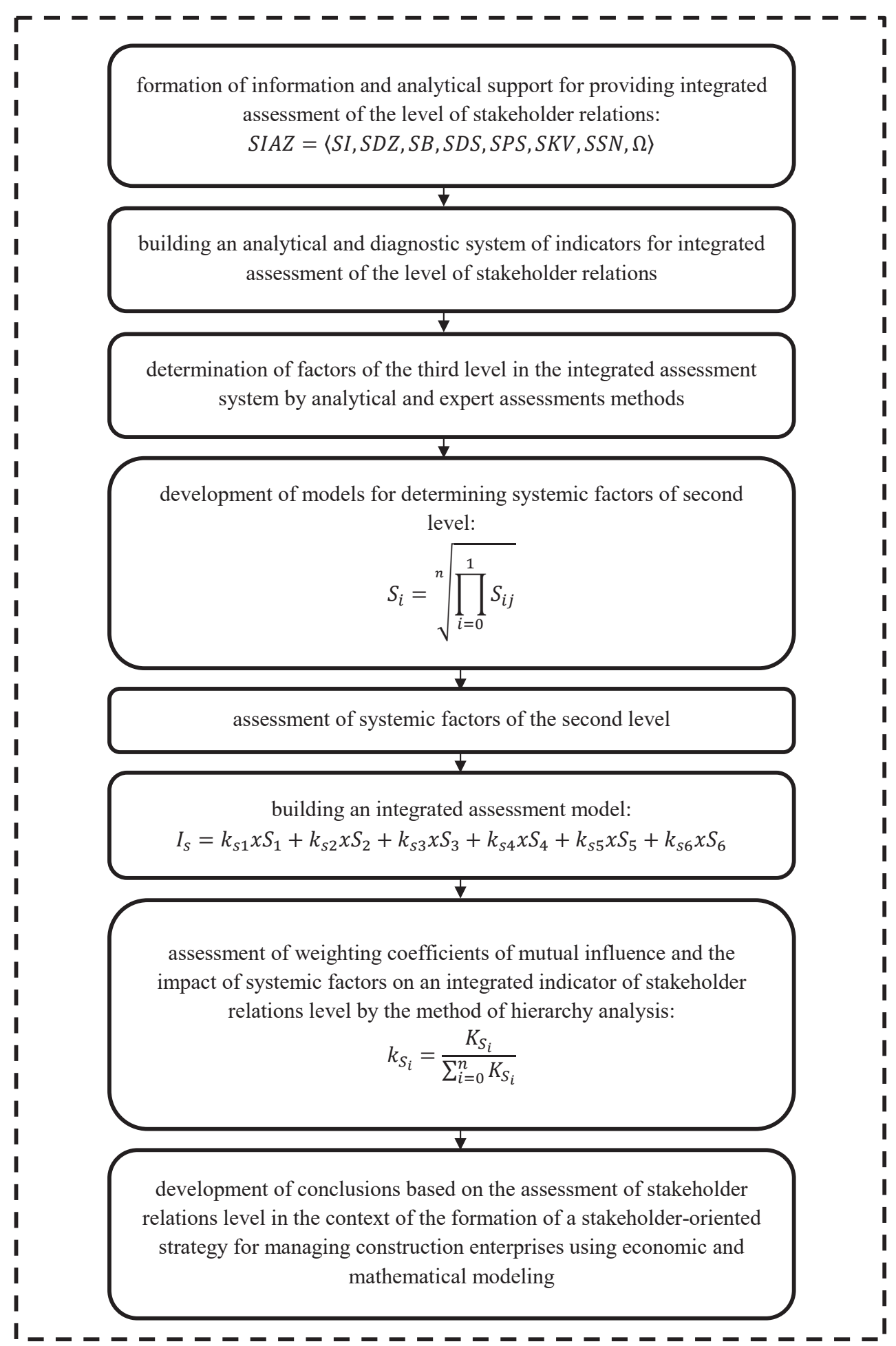

Figure 1. Scheme of methodological approach development for integrated assessment of the stakeholder relations level

A multi-level analytical and diagnostic system of indicators for integrated assessment of stakeholder relations level allows to determine the relationship between indicators, to make the transition from local factors to systemic ones, and makes it possible to consider a significant number of features and characteristics, which affect stakeholder relations. At the same time, a multi-level system of indicators creates the basis for the formation of a quantitative basis for a stakeholderoriented strategy for managing construction enterprises.

Thus, a methodological approach to an integrated assessment of the level of stakeholder relations of 
construction enterprises has been proposed. This creates a quantitative basis for developing a stakeholder-oriented strategy for construction enterprise management and making managerial decisions aimed at increasing investment attractiveness. The methodological approach includes a system of factors, which consider the quality and level of contractual obligations fulfillment, directions and peculiarities of investigated construction enterprises interaction with different groups of stakeholders, formation, and implementation of corporate management of construction enterprises to ensure interaction with interested parties, strategic directions of their functioning, socio-economic and innovative level of construction enterprises.

To form a quantitative basis for making managerial decisions, it is proposed to establish causal relationships between the integrated indicators of investment attractiveness and the level of stakeholder relations of construction enterprises by constructing an economic and mathematical model. At the same time, criteria for the adequacy of this model, which determines the causal relationships between the integrated indicators of investment attractiveness and the level of stakeholder relations of construction enterprises, are proposed, the characteristics of which are presented in Table 3.
The correlation and determination coefficient defines the level of influence of the independent variable $x$ (the integrated indicator of stakeholder relations level) on the dependent factor $y$ (the integrated indicator of investment attractiveness). The Student's t-test determines the feasibility of the established links between the integrated indicators of stakeholder relations level and the investment attractiveness of construction enterprises. Fisher's F-test criterion determines the level of materiality and significance of the established relationships between integral indicators. The criteria of homo or heteroskedasticity determine the homogeneity degree of the residual indicators of the economic and mathematical model. Durbin-Watson test (DW) criterion is used to determine the autocorrelation of residuals.

The phenomenon of multicollinearity leads to a shift in estimates of the economic and mathematical modeling results, which reduces the effectiveness of the study. The level of multicollinearity is as follows: the correlation coefficient between the independent variables is 0 - no multicollinearity; 0.01 0.2 - low multicollinearity; $0.201-0.4$ - insignificant; 0.401 - 0.6 - moderate; $0.601-0.8$ - significant; $0.801-0.99$ - high; 1 - absolute.

Table 3

Criteria for the adequacy of the economic and mathematical model, rel. units

\begin{tabular}{|c|c|}
\hline Adequacy criterion & Model \\
\hline The correlation coefficient $(R)$ & $\begin{array}{l}\qquad R=\frac{\sum_{i=1}^{n}\left(X_{i}-\bar{X}\right) x\left(Y_{i}-\bar{Y}\right)}{\sqrt{\sum_{i=1}^{n}\left(X_{i}-\bar{X}\right)^{2}} x \sum_{i=1}^{n}\left(Y_{i}-\bar{Y}\right)^{2}} \\
\text { where } X_{i}, Y_{i} \text { are the values between which relationships are established (an integrated } \\
\text { indicator of investment attractiveness and an integrated indicator of the level of stakeholder } \\
\text { relations of construction enterprises); } \bar{X}, \bar{Y} \text { are the average values of integrated indicators }\end{array}$ \\
\hline Determination coefficient $\left(R^{2}\right)$ & $R^{2}=\sqrt{R}$ \\
\hline Student's t-test & $\begin{array}{l}\qquad t=\frac{M_{1}-M_{2}}{\sqrt{m_{1}^{2}+m_{2}^{2}}} \\
\text { where } M_{1}, M_{2} \text { are the arithmetic average values of integrated indicators of the level of } \\
\text { stakeholder relations and investment attractiveness of construction enterprises; } m_{1}, m_{2} \text { are the } \\
\text { values of statistical errors of integrated indicator arithmetic average }\end{array}$ \\
\hline Fisher's F-test & $\begin{array}{l}\qquad F=\frac{R^{2}}{1-R^{2}} x \frac{(n-m-1)}{m} \\
\text { where } \mathrm{n} \text { is the number of observations regarding integrated indicators of stakeholder relations } \\
\text { and investment attractiveness levels }\end{array}$ \\
\hline Homo or heteroskedasticity test criteria & are determined by Goldfeld-Quandt, Glacier models, by $\mu$-criterion \\
\hline Durbin-Watson test $(D W)$ & $\begin{array}{l}\text { the Durbin-Watson test is determined (DW): } \\
\qquad D W=\frac{\sum\left(e_{i}-e_{i-1}\right)^{2}}{\sum e_{i}^{2}} \\
\text { where } e_{i}, e_{i-1} \text { are the remains of integrated indicators of the of stakeholder relations and } \\
\text { investment attractiveness levels }\end{array}$ \\
\hline Multicollinearity Test Criteria & $\begin{array}{l}\text { the level of influence of one independent variable on another independent variable is estimated } \\
\text { by the corresponding pair correlation coefficient }\end{array}$ \\
\hline
\end{tabular}




\section{Empirical results}

The results of the integral indicator estimation of the investment attractiveness level are presented in Table 4.

Table 4

The results of the integrated indicator estimation of the investment attractiveness level, rel. units.

\begin{tabular}{|l|c|}
\hline Construction enterprises & $\begin{array}{l}\text { The value of the integrated } \\
\text { indicator of the investment } \\
\text { attractiveness level }\end{array}$ \\
\hline JSC “Kyivmiskbud” & 2.57 \\
\hline $\begin{array}{l}\text { Brovarsky Plant of Building } \\
\text { Structures }\end{array}$ & 3.12 \\
\hline JSC “KDBK” & 2.44 \\
\hline PJSC “Trust Zhitlobud-1" & 2.82 \\
\hline $\begin{array}{l}\text { LLC Construction Company } \\
\text { "Miskzhitlobud” }\end{array}$ & 2.07 \\
\hline PJSC “Capital Real Estate” & 4.5 \\
\hline JSC “Zhitlobud-2” & 1.87 \\
\hline $\begin{array}{l}\text { Ukrainian State Building } \\
\text { Corporation “UkrBud” }\end{array}$ & 1.61 \\
\hline Construction group “Fundament” & 1.82 \\
\hline
\end{tabular}

Based on the study, the groups of construction companies have been identified by the level of investment attractiveness:

1. Low: JSC "Zhitlobud-2", Ukrainian State Building Corporation "UkrBud", Construction group "Fundament".

2. Insignificant: JSC "Kyivmiskbud", JSC "KDBK", PJSC “Trust Zhitlobud-1", LLC Construction Company "Miskzhitlobud".

3. Moderate: Brovarsky Plant of Building Structures, PJSC "Capital Real Estate”.

A quantitative basis for determining the investment attractiveness of construction enterprises has been formed, which allows to make justified management decisions aimed at its growth. The results of the study indicate a low or insignificant level of investment attractiveness of most construction enterprises. Moderate values of the integrated indicator approach the limit of an insignificant level. This requires the formation and implementation of systemic actions to increase investment attractiveness by increasing the effectiveness of interaction with stakeholders of construction enterprises as part of a stakeholderoriented strategy for their management.
As a result of applying the methodological approach to the integrated assessment of stakeholder relations level, the corresponding integral factor is determined: JSC "Kyivmiskbud": $I_{s}=5.84$; Brovarsky Plant of Building Structures: $I_{s}=4.85$; JSC "KDBK": $I_{s}=4.97$; PJSC “Trust Zhitlobud-1": $I_{s}=4.96$; LLC Construction Company "Miskzhitlobud": $I_{s}=4.39$; PJSC "Capital Real Estate": $I_{s}=4.8$; JSC "Zhitlobud-2": $I_{s}=4.82$; Ukrainian State Building Corporation "UkrBud": $I_{s}=4.9$; Construction group "Fundament": $I_{s}=4.82$.

Thus, as a result of the assessment, an integral indicator of stakeholder relations level has been determined, which allows to stablish that JSC "Kyivmiskbud" has been characterized by the highest value of this criterion. However, as at other construction enterprises, it has been determined by a moderate level, which indicates the inconsistency of measures to form and implement contractual obligations, the interaction of stakeholders in the areas of functioning of construction enterprises, the formation and implementation of corporate governance in the system of relationships between interested parties, strategic areas, unsystemic formation and implementation of socio-economic and innovative directions when interacting with interested parties, the lack of a system for the formation and determination of the strategic state indicators of construction enterprises, and ensuring their permanent monitoring.

Using information and analytical support, the economic and mathematical model for the relationship between the generalizing factor of stakeholder relations level and the integral indicator of construction enterprises investment attractiveness has been developed:

$$
I A=-0.47 x I_{s}^{2}+5.06 x I_{s}-10.99 \text {. }
$$

The indicators that determine the degree of relationship between the indicators are as follows: $R=0.004, R^{2}=0.02$.

The values of the correlation and determination coefficients indicate their low interconnection, the generalizing factor of stakeholder relations level determines the change in the integrated indicator of investment attractiveness of construction enterprises only by $2 \%$.

The criteria for the adequacy of the economic and mathematical model of the relationship between the generalizing factor of the level of stakeholder relations of construction enterprises and the integral indicator of their investment attractiveness are presented in Table 5.

Table 5

The results of determining the criteria for the adequacy of the economic and mathematical model, rel. units

\begin{tabular}{|l|c|c|}
\hline \multicolumn{1}{|c|}{ Criterion } & Calculated values & Normative values \\
\hline Fisher's F-test $(F)$ & $F_{I_{s}}=3.6$ & $F_{H}=3.44$ (at the level of significance $=0.05$ ) \\
\hline Student's t-test $(t)$ & $t_{I_{s}}=2.62$ & $t_{H}=2.31$ (at the level of significance $=0.05$ ) \\
& $t_{p}=2.37$ & $M_{\text {norm }}=2.36$ \\
\hline Homo or heteroskedasticity test criteria & $\mathrm{M}_{\text {calc }}=1.74$ & $D W_{U}=0.68$ \\
\hline Durbin-Watson test $(D W)$ & $D W_{\text {calc }}=0.16$ & - \\
\hline Multicollinearity Test Criteria & - & \\
\hline
\end{tabular}


The interpretation of the economic and mathematical modeling results indicates the ambiguity of the influence of the generalizing factor of stakeholder relations level on the integral indicator of construction enterprise investment attractiveness. In particular, it was established that most of the adequacy criteria indicate the reliability of the established relationships and the appropriateness of the developed economic and mathematical model. At the same time, as indicated by the value of the calculated Durbin-Watson test, the heterogeneity of the residues is observed. The low level of connection between the generalizing factor of stakeholder relations level and the integral indicator of construction enterprises investment attractiveness indicates the insufficient focus of these enterprises on ensuring effective interaction with stakeholders. Therefore, there is a need to develop and implement a stakeholder-oriented strategy for managing construction enterprises to ensure the growth of their investment attractiveness.

\section{Conclusion}

As a result of the study, the conceptual apparatus of economic science has been improved, in particular, the concept of "stakeholders of construction enterprises" has been introduced into the functional field of effective enterprise management, which, unlike the established ones, is determined by a combination of operational, resulting, structural, process, strategic and complex features. The relationships of stakeholders have a certain level of risk and threats, form strategic directions and ensure the efficiency of construction enterprises, form contractual relations in capital construction, carry out architectural control, relevant calculations, which are provided by project documentation, material, and labor resources.

The created topological foundations for the determination of stakeholder groups of construction enterprises based on the essential characteristics of customers of construction products, workers, top management, owners, government bodies, corporate governance bodies, design organizations, other stakeholders, which, unlike the existing ones, allows to form an analytic and diagnostic system of stakeholder indicators for development and implementation of a methodology for the integrated assessment of stakeholder relations level.

The processes of economic and mathematical modeling of the investment attractiveness of construction enterprises through the formation and implementation of stakeholder relations are substantiated by determining the relationship between the investment attractiveness integrated indicator and the generalizing factor of stakeholder relations level based on the application of correlation and regression analysis methods, model adequacy criteria, which allows to develop strategic directions for the development of construction enterprises.

\section{References:}

Ackoff, R. (1972). Planning in large economic systems. Moscow: Sovetskoe radio. (in Russian)

Ackoff, R., \& Emery, F. (2005). On purposeful systems: an interdisciplinary analysis of individual and social behavior as a system of purposeful events. 2nd ed. New York: Aldine Transaction.

Bilyak, N. I. (2006). Assessment and ways to improve the investment attractiveness of the agricultural sector of the economy. PhD (econ) thesis. Lviv: State Agrarian University. (in Ukrainian)

Budnikova, Y. V. (2011). Investment attractiveness of the enterprise and factors influencing it. Innovative Economy, vol. 4(23), pp. 194-197. (in Ukrainian)

Burkovets, O. S. (2012). Increasing the investment attractiveness of enterprises. PhD (econ) thesis. Luhansk: SNU named after V. Dahl. (in Ukrainian)

Chervanev, D. M. (2003). Management of investment activities of enterprises: textbook. Kyiv: Knowledge Press. (in Ukrainian)

Cleland, D. (2004). Project stakeholder management, In: Pinto, J.K. (Eds.), Project Management, Part 1. Moscow. D’Anselmi, P. (2011). Values and stakeholders in an era of social responsibility. New York: Free Press.

Dearden, J. (1987). Measuring profit center managers. Harvard Busin. Rev., vol. 65, pp. 84-88.

Donaldson, T., \& Preston, L. (1997). The stakeholder theory of the corporation: concepts, evidence, and implications. Acad. Manag. Rev., vol. 1, pp. 65-66.

Dudka, A. I., \& Lysenko, Yu. G. (1999). Comprehensive rating assessment of investment attractiveness of enterprises. Prometheus, vol. 1, pp. 149-162. (in Russian)

Duka, A. P. (2008). Theory and practice of investment activities. Investing: textbook. Kyiv: Karavela. (in Ukrainian)

Florko, V. (2003). Assessment of investment attractiveness of the enterprise: problems of risk accounting and reducing its level. Regional Economy, vol. 4, pp. 190-199. (in Ukrainian)

Kolchkova, O. V. (2011). Retail trade measures: regional development factors. PhD (econ) thesis. Kharkiv. (in Ukrainian)

Korotkova, O. V. (2013). Investment attractiveness of the enterprise and its evaluation methods. Efektyvna ekonomika. Available at: http://www.economy.nayka.com.ua/?op=1\&z=2132

Kostyuk, T. I. (2005). Investment attractiveness of Ukraine's economy: realities and prospects. Bulletin of the Donetsk Institute of Social Education, vol. 1(1), pp. 48-58. (in Ukrainian) 
Krylova, E. I., Vlasova, V. M., Egorova, M. G. et al. (2003). Analysis of the financial condition and investment attractiveness of the enterprise: textbook. Moscow: Finance and statistics. (in Russian)

Kuntsevich, V. O. (2005). Approaches to the diagnosis of the financial potential of the Enterprise. Actual problems of economics, vol. 1, pp. 68-75. (in Ukrainian)

Laiko, G. P. (2005). Formation of investment attractiveness of agro-industrial enterprises. Kyiv: National scientific center "Institute of agricultural economy". (in Ukrainian)

Leshchenko, M. (2001). Analysis of the investment attractiveness of companies. Rynok tsennykh bumag, vol. 14(197), pp. 62-64. (in Russian)

Maidanevich, P. N. (2004). Estimation of investment attractiveness of NPAO "Massandra”. Bulletin of KhNAU, vol. 10, pp. 200-212. (in Russian)

Malova, T. L., \& Silverstova, L. S. (2003). Development of methodical bases of a rating estimation of investment attractiveness of joint-stock companies. Actual problems of economics, vol. 2(20), pp. 40-43. (in Ukrainian)

Mayorova, T. V. (2004). Investment activity: textbook. Kyiv: Tsentr navchalnoi literatury. (in Ukrainian)

Orlykovsky, M. O. (2007). Assessment of investment attractiveness of agricultural production in the region. Ekonomika APK, vol. 1, pp. 94-98. (in Ukrainian)

Ovdiy, L. I., \& Nekrasova, Ya. A. (2009). Evaluation of the attractiveness of enterprises using statistical models. Economic sciences, vol. 4(2), pp. 184-188. (in Ukrainian)

Parmar, B. L., Freeman, R. E., Harrison, J. S. Wicks, A. C., Purnell, L., \& de Colle, S. (2010). Stakeholder theory: The state of the art. The Academy of Management Annals, vol. 4(1), pp. 403-445. doi: 10.1080/19416520.2010.495581 Pilyushenko, V. L., \& Shkrobak, I. V. (2000). Methodological aspects of assessing the investment potential of enterprises. Manager, vol. 5,pp. 107-112. (in Russian)

Post, J. E., Preston, L. E., \& Sachs, S. (2002). Redefining the corporation: Stakeholder management and organization wealth. Stanford: Stanford University Press.

Preston, L. (2004). Boards and company performance - research challenges the conventional wisdom. Corporate Governance: an International Review, vol. 11(3), p. 151.

Rud, L. P. (2006). Economic justification of investment activity in agriculture. PhD (econ) thesis, Kharkiv National Agrarian University. Kharkiv. (in Ukrainian)

Sabluk, P. T., Kisil, M. I., \& Kodenska, M. Yu. (2005). Investment of agrarian and industrial production in Ukraine. In: Kisil, M. I., Kodenska, M. Yu. (Eds.). Kyiv: National scientific center "Institute of agricultural economy", 478 p. (in Ukrainian)

Savchuk, V. P., Prilipko, S. I., \& Velichko, E. G. (1999). Analysis and development of investment projects. Kyiv: Absolute - V. Elga.

Shiyan, D. V., \& Strochenko, N. I. (2003). Financial analysis: textbook. Kyiv: A.S.K. (in Ukrainian)

Shportko, H. Yu., Kozenkova, N. P., \& Kozenkova, V. D. (2014). Evaluation of investment appeal of production enterprise. Efektyvna ekonomika, vol. 11. Available at: http://www.economy.nayka.com.ua/?op=1\&z=3550

Stalinskaya, E. (2003). Assessment of investment attractiveness of the regions of Ukraine. Economist, vol. 9, pp. 68-69. (in Russian)

State Statistics Service of Ukraine (2011). Retail trade of Ukraine in 2000-2010 In: Pischeyko V. (Eds.). Kyiv: State Statistics Service of Ukraine. (in Ukrainian)

Valinurova, L. S., \& Kazakova, O. B. (2005). Investment management: a textbook. Moscow: Knorus. (in Russian) Vlasova, N. O., \& Bezginova, L. I. (2006). Formation of optimal capital structure in retail enterprises. Kharkiv: Kharkiv State University of Nutrition and Trade. (in Ukrainian)

Vovchak, O. D. (2006). Investing: textbook. Lviv: New World. (in Ukrainian)

Yukhimchuk, S. V., \& Suprun, S. D. (2003). Matrix model for assessing the investment attractiveness of industrial enterprises. Enterprise finance, vol. 1, pp. 3-12. (in Ukrainian)

Yuriy, S., \& Hubanova, L. (2005). The research of Ukrainian regions relative investment attractiveness. World of Finance, vol. 1, pp. 108-118. (in Ukrainian)

Zhuvagina, I. A. (2013). Evaluation of business climate retailers. Investytsiyi: praktyka ta dosvid, vol. 8. Available at: http:/9www.investplan.com.ua/pdf/8_2013/6.pdf (in Ukrainian)

Zyatkovsky, I. V. (2003). Finance of enterprises: textbook. 2nd ed. Kyiv: Condor. (in Ukrainian) 